\title{
Prediksi Penjualan Kertas Menggunakan Metode Double Exponential Smoothing
}

\author{
Erinsyah Aditya Nugroho Putro'); Elistya Rimawati'); Retno Tri Vulandari ${ }^{3)}$ \\ 1,2) Program Studi Sistem Informasi, STMIK Sinar Nusantara Surakarta \\ 3)Program Studi Teknologi Informasi, STMIK Sinar Nusantara Surakarta \\ 1)erinsyahaditya@gmail.com; ${ }^{2}$ elistya@sinus.ac.id ; ${ }^{3)}$ retnotv@sinus.ac.id
}

\begin{abstract}
The important thing on carry out the business is keeping of goods and services. The purpose of the business will be reached when the owner knowing the total of goods supply in their business. The function using materials selling prediction model on printing business is to estimate and calculate their selling prediction. That model used to minimize economic damage when the costumer canceled order because of the materials uncompleted well and prevent the paper damage in order to materials don't save at the warehouse to long. This research used Double Exponential Smoothing method to know the selling prediction between Paper $A$ and paper HVS A3+. It is also to calculate the error prediction using MAPE (Mean Absolute Percentage Error). The purpose of this study is creating an accurate forecasting application. The form of the prediction result from this application on the next month will be used to buy the paper. The research result on Paper A dan HVS A3 +is getting the best alpha on 12 period with the value 0.3 and 0.6 using a MAPE error of $12 \%$ and $18 \%$. The value of accuracy level is $88 \%$ and $82 \%$ which used the alpha to predict the 13 period. The value of prediction on paper $A$ is 446 and the value of prediction on paper HVS A3 + is 474.
\end{abstract}

Keywords: Printing, Double Exponential Smoothing, Forecasting

\section{PENDAHULUAN}

Persaingan antar berbagai industri dan bisnis baik sejenis maupun tidak di era globalisasi ini terjadi sangat ketat. Perkembangan dunia teknologi informasi yang cepat dan pesat juga mengakibatkan persaingan dalam dunia bisnis menjadi rumit dan kompleks. Salah satu hal yang penting dalam bisnis yaitu persediaan barang dagang, Persediaan barang dagang merupakan faktor dalam menentukan keberhasilan dari perusahaan dagang untuk mencapai tujuannya, karena barang yang dijual mempengaruhi tingkat pendapatan untuk meningkatkan laba perusahaan [1].

Percetakan merupakan perusahaan yang menyediakan berbagai jasa cetak kertas, desain, dan lain sebagainya. Di mana ketersediaan bahan baku merupakan hal yang paling penting guna menunjang penjualan. Ketersediaan bahan baku berlebihan dapat menjadi kerugian bagi perusahaan pula, karena bahan baku kertas jika disimpan terlalu lama akan menyebabkan kerusakan bahan baku. Maka dari itu peramalan penjualan sangat dibutuhkan karena dengan hal tersebut pemilik dapat mengetahui jumlah ketersediaan bahan baku yang ada [2].

Salah satu metode yang dapat diterapkan untuk meramal penjualan kertas di percetakan yaitu dengan Double Exponential Smooting.
Kelebihan dari metode ini dapat memodelkan trend dan tingkat dari suatu deret waktu lebih efisien dibandingkan metode lain, karena memerlukan data yang lebih sedikit, dan menggunakan satu parameter sehingga menjadi lebih sederhana [3].

Penelitian ini berfokus pada prediksi peramalan penjualan kertas Paper A dan HVS $\mathrm{A} 3+$ di Percetakan. Kedua kertas tersebut memiliki resiko kerusakan tinggi dan paling banyak digunakan. Tujuan penelitian ini dapat membantu Percetakan dalam pengambilan keputusan pembelian bahan baku pada bulan berikutnya agar lebih maksimal.

\section{TINJAUAN PUSTAKA}

\subsection{Sistem}

Sistem adalah kumpulan dari elemenelemen yang berinteraksi untuk mencapai suatu tujuan tertentu. Sistem ini menggambarkan suatu kejadian-kejadian dan kesatuan yang nyata adalah suatu objek nyata, seperti tempat, benda, dan orangorang yang betul-betul ada dan terjadi[4].

\subsection{Decision Support System (DSS)}

Decision Support System yaitu sebuah sistem yang mendukung pengambilan keputusan didalam situasi tertentu. DSS dibuat dengan tujuan untuk menjadi tambahan bagi para pembuat keputusan untuk 
memperluas kemampuan didalam merencanakan sesuatu, tetapi tidak menghilangkan penilaian dari pembuat keputusan. Sistem pendukung keputusan menggunakan model analitis, database, penilaian dan pandangan untuk membuat suatu keputusan. Sistem ini juga dapat dikatakan sebagai sistem komputer yang mengolah data menjadi informasi untuk mengambil keputusan dari masalah semiterstruktur yang spesifik[5].

\subsection{Peramalan}

Peramalan adalah sebuar teknik untuk memperkirakan keadaan dimasa yang akan datang melalui pengujian keadaan dimasa lalu dengan peramalan ini selalu berupaya untuk meminimumkan ketidak pastian terhadap suatu masalah [6]. Kegunaan ramalan ini terlihat saat dilakukanya pengambilan keputusan, keputusan yang baik didapat dengan atas dasar penggunaan pertimbangan-pertimbangan yang terjadi saat keputusan dibuat [6].

\subsubsection{Penentuan pola data}

Ada beberapa pola data yang perlu di perhatikan dalam melakukan peramalan menurut[6], yaitu:

a. Pola data horizontal

Pola ini terjadi jika terdapat data yang berfluktuasi disekitar nilai rata-rata yang konstan atau sejajar. Suatu produk yang penjualannya tidak meningkat atau menurun selama waktu tertentu termasuk jenis pola ini. Pola khas dari data horizontal atau stasioner [6]. Seperti pada Gambar 1.

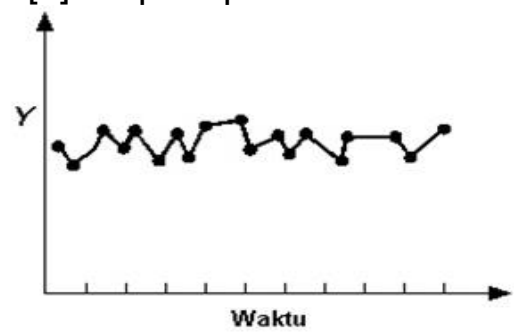

Gambar 1. Pola Data horizontal

b. Pola Data Musiman

Pola data ini terjadi jika terdapat suatu deret data yang dipengaruhi oleh faktor musiman (misalnya kuartal tahun tertentu, bulanan, atau hari-hari pada minggu tertentu) Penjualan dari produk seperti minuman ringan, es krim, dan bahan bakar pemanas ruang semuanya menunjukan jenis pola ini [6], Terlihat pada Gambar 2:

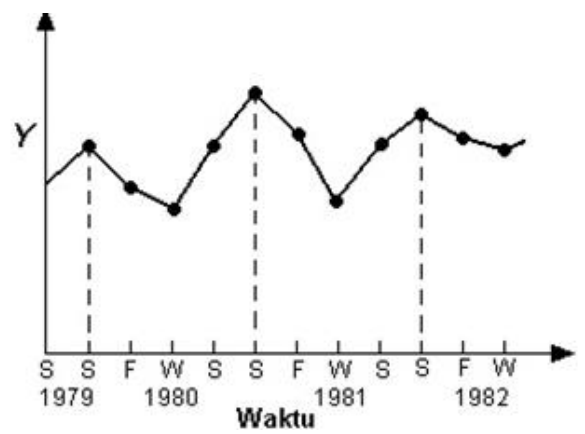

Gambar 2. Pola Data Musiman

c. Pola Data Siklus

Pola data ini terjadi jika terdapat data yang dipengaruhi oleh fluktuasi ekonomi jangka panjang seperti yang berhubungan dengan siklus bisnis, Contoh : penjualan produk seperti mobil, baja, dan peralatan utama lainya [6]. Jenis pola ini dapat dilihat pada Gambar 3:

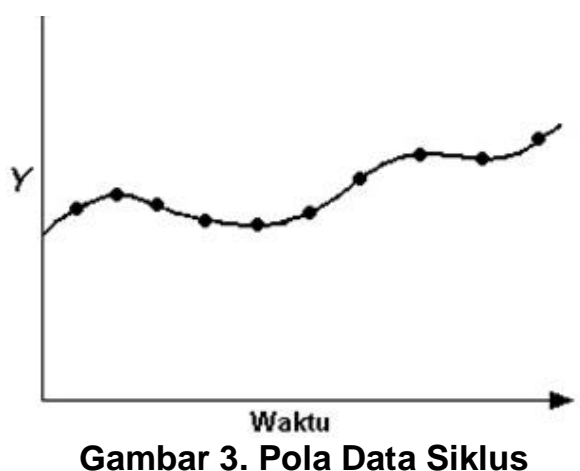

d. Pola Data Trend

Pola data trend terjadi jika terdapat kenaikan atau penurunan sekuler jangka panjang dalam data[6]. Contoh : penjualan banyak perusahaan, Jenis pola ini dapat dilihat pada Gambar 4 sebagai berikut :

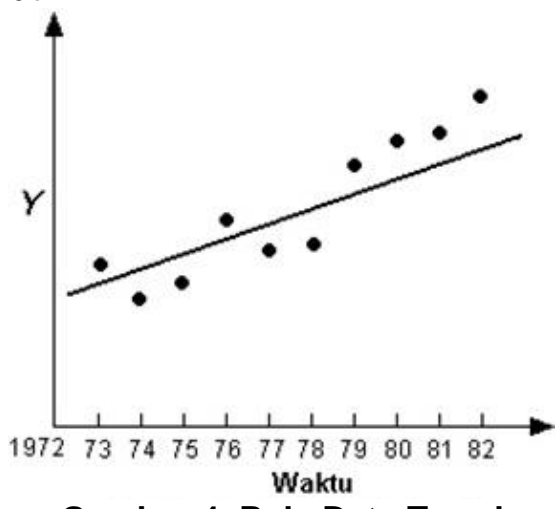

Gambar 4. Pola Data Trend

\subsection{Metode Double Exponential Smooting}


Metode double exponential smoothing adalah metode peramalan satu linier yang dikemukan oleh Brown, peramalan ini melakukan pemulusan tunggal kemudian dilakukan lagi dengan pemulusan ganda. Metode double exponential smoothing biasa digunakan untuk meramalkan pola data yang berunsur trend [7]. Rumus yang dipakai dalam implementasi Double Exponential Smoothing dari Brown ditunjukkan di bawah ini menurut [8]:

a. Menentukan Smoothing pertama ( S't )

$S^{\prime} t=\alpha X t+(1-\alpha) S^{\prime} t-1$,

$X t$ adalah nilai aktual periode ke-t

$\alpha$ adalah parameter smoothing

b. Menentukan Smoothing kedua ( S"t )

$S^{\prime \prime} t=\alpha S^{\prime} t+(1-\alpha) S^{\prime \prime} t-1$,

a adalah parameter smoothing

c. Menentukan besarnya Konstanta ( at )

at $=2 S^{\prime} \mathbf{t}-S^{\prime \prime} \mathbf{t}$

d. Menentukan besarnya Slope (bt )

$b t=\alpha /(1-\alpha)\left(S^{\prime} t-S^{\prime \prime} t\right)$

$\alpha$ adalah parameter smoothing

e. Menentukan besarnya forecast ( $\mathrm{Ft}+\mathrm{m}$ )

$\mathbf{F t}+\mathbf{m}=\mathbf{a t}+\mathbf{b t} \mathbf{m}$,

Keterangan:

S't : nilai pemulusan eksponensial tunggal pada periode ke-t

S't-1 : nilai pemulusan eksponensial tunggal pada periode ke-(t-1)

S"t : nilai pemulusan eksponensial ganda pada periode ke-t

S"t-1 : nilai pemulusan eksponensial ganda pada periode ke-(t-1)

Xt : data aktual time series pada periode ke-t

a : parameter pemulusan eksponensial, $0<\boldsymbol{\alpha}<1$

at,bt : konstanta pemulusan pada periode ke-t

$\mathrm{Ft}+\mathrm{m} \quad$ : hasil peramalan untuk periode ke depan yang diramalkan $\mathrm{M}$ adalah jumlah periode kemuka yang diramalkan.

M : jumlah periode ke depan yang diprediksi

\subsection{MAPE (Mean Absolute Percentage Error)}

Nilai kesalahan absolut atau Mean Absolute percentage error (MAPE), merupakan salah satu metode yang di gunakan dalam menghitung kesalahan prediksi (forecast error), MAPE merupakan perhitungan presentase dari Absolute Percentage Error (APE) pada masin-masing periode lalu di cari rata-rata dengan MAPE [9]:
$\mathrm{APE}=\left|\frac{A_{t}-F_{t}}{A_{t}}\right| \times 100 \%$

MAPE $=\frac{|\Sigma A P E|}{n}$

Keterangan :

$A_{t}=$ nilai aktual pada waktu ke $\mathrm{t}$

$F_{t}=$ nilai prediksi pada waktu ke $\mathrm{t}$

$n$ = banyak data

| | = nilai absolut

\subsection{Penelitian Terkait}

Karmawati pada penelitiannya menghasilkan sebuah aplikasi sistem Peramalan Persediaan Elektronik Menggunakan Metode Single Exponential Smoothing dan Double Exponential Smoothing yang dapat digunakan untuk meramalkan jumlah persediaan penjualan elektronik. Ramalan penjualan Speaker Aktif/Polytron/PAS 200 memiliki nilai Mean Squared Error (MSE) yang terkecil terdapat pada metode Double Exponential Smoothing (DES) adalah 36.9455. Pada tahap uji sampel didapat bahwa peramalan penjualan barang elektronik yang tertinggi dengan metode Double Exponential Smoothing pada Speaker Aktif/Polytron/PAS 200 adalah yang terdapat pada tahun 2016 berjumlah 308 unit [2] .

M. N. Fawaiq pada penelitannya metode Brown's Double Exponential Smoothing bisa diterapkan untuk memprediksi produksi padi di Kabuapaten Kudus. Pada 9 kecamatan di Kabupaten Kudus menunjukan hasil prediksi produksi padi pada tahun 2019 sebesar $163,435,90$ ton dan nilai MAPE (Mean Absolute Percentage Error) sebesar 8.64\%, berdasarkan nilai tersebut maka prediksi tergolong dalam kategori tingkat kesalahan rendah karena presentase kesalahan kurang dari $10 \%$ [3].

\section{METODE PENELITIAN}

\subsection{Sumber Data}

Data pada penelitian ini diperoleh melalui media perantara atau secara tidak langsung yang berupa buku, catatan, bukti yang telah ada, atau arsip baik yang dipublikasikan maupun yang tidak dipublikasikan secara umum. Data ini meliputi data penjualan kertas Paper A dan Hvs A3+ pada Percetakan. 


\subsection{Metode Pengumpulan Data}

Teknik pengumpulan data yang digunakan dalam penelitian ini adalah dengan menggunakan metode observasi, wawancara, dan kepustakaan.

\subsubsection{Metode Observasi}

Metode ini dilakukan dengan langsung di lokasi Percetakan, observasi dilakukan guna melihat langsung proses bisnis yang berjalan. Data yang dikumpulkan berupa: menganalisa data penjualan kertas Paper A dan HVS A3+ pada Percetakan.

\subsubsection{Metode Wawancara}

Pengumpulan data yang dilakukan dengan wawancara, dengan mengajukan pertanyaan kepada pimpinan yang berwenang mengelola data penjualan. Metode dilakukan dengan lisan sehingga dijawab dengan lisan oleh pimpinan. Cara ini untuk mendapatkan keterangan-keterangan pelengkap guna kelancaran kegiatan penelitian pada bidang yang akan diteliti. Data yang diperoleh berupa informasi tentang data penjualan yang paling sering terjadi, sejarah perusahaan, struktur organisasi.

\subsubsection{Metode Kepustakaan}

Kepustakaan adalah sebuah cara mengumpulkan data dengan menggunakan pustaka-pustaka yang telah ada untuk digunakan sebagai referensi. Pada tahap ini dilakukan pengumpulan data melalui studi literature yaitu mengumpulkan bahan-bahan referensi baik dari buku, artikel, jurnal, makalah, maupun situs internet mengenai sistem pendukung keputusan menggunakan metode Double Exponential Smoothing dan beberapa referensi lain yang menunjang tujuan dari penelitian ini.

\subsection{Metode Analisa}

Tahapan ini menentukan analisa metode yang digunakan dalam penelitian ini yang terdiri dari:

\subsubsection{Double Exponential Smooting}

Penggunaan metode Double exponential smoothing yaitu guna menghitung data penjualan yang sudah diperoleh, guna menghasilkan nilai peramalan yang nantinya akan di lakukan pengujian nilai error dari hasil peramalan tersebut apakah hasil yang di dapat dinyatakan berhasil. Yaitu menggunakan rumus (1) untuk pemulusan pertama dan rumus (2) untuk pemulusan kedua

\subsubsection{MAPE (Mean Absolute Percentage \\ Error)}

Pengunaan metode MAPE adalah guna menghitung ketepatan peramalan dengan rumus (7), Dalam penerapannya semakin kecil nilai MAPE maka nilai peramalan akan mendekati nilai sebenarnya. Kemampuan prediksi berarti sangat baik jika nilai MAPE dengan rata-rata kurang dari $10 \%$ dan mempunyai kemampuan prediksi yang baik jika rata-rata nilai MAPE kurang dari $20 \%$ [3].

\subsection{Tahap Perancangan Sistem}

Tahapan pembuatan perancangan adalah dengan membuat Diagram Konteks, selanjutya dibuat Data Flow Diagran (DFD). Sistem terdiri dari Desan Input, Desain Output, Desain Teknologi dan Desain Database. Setelah Implementdiasi Sistem dilakukan Pengujian Sistem seperti Gambar 5.

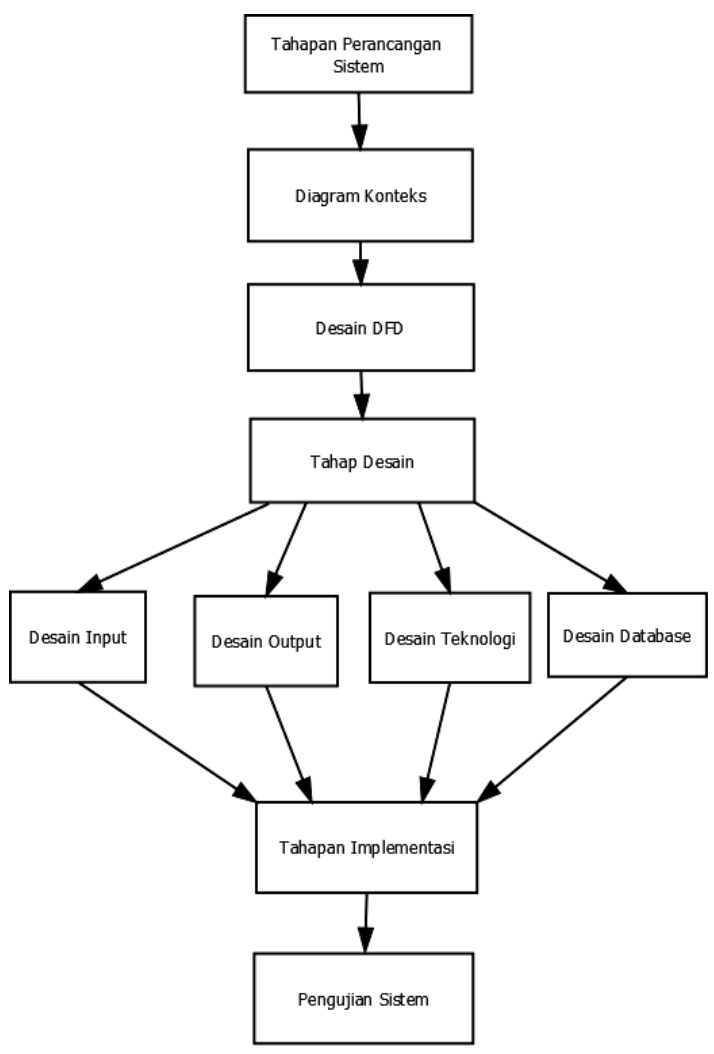

Gambar 5 Diagram Perancangan Sistem

\section{HASIL DAN PEMBAHASAN}

\subsection{Data penjualan}

Berikut data penjualan kertas 1 tahun Paper A dan HVS A3+ yang diambil mulai tahun Juli 2018 hingga Juni 2019 Dari Percetakan ditunjukkan pada Tabel 1. 
Tabel 1. Analisis data penjualan

\begin{tabular}{|c|c|c|}
\hline BULAN & $\begin{array}{c}\text { KERTAS } \\
\text { PAPER A }\end{array}$ & $\begin{array}{c}\text { KERTAS } \\
\text { HVS A3 }\end{array}$ \\
\hline JULI 2018 & 1000 & 1256 \\
\hline AGUSTUS 2018 & 850 & 775 \\
\hline SEPTEMBER 2018 & 750 & 625 \\
\hline OKTOBER 2018 & 660 & 665 \\
\hline NOVEMBER 2018 & 773 & 515 \\
\hline DESEMBER 2018 & 607 & 525 \\
\hline JANUARI 2019 & 715 & 640 \\
\hline FEBRUARI 2019 & 620 & 615 \\
\hline MARET 2019 & 570 & 520 \\
\hline APRIL 2019 & 530 & 485 \\
\hline MEI 2019 & 605 & 450 \\
\hline JUNI 2019 & 510 & 495 \\
\hline
\end{tabular}

Data penjualan akan dijadikan plot grafik supaya dapat dianalisa, hasil plot ditunjukkan pada Gambar 6 dan Gambar 7.

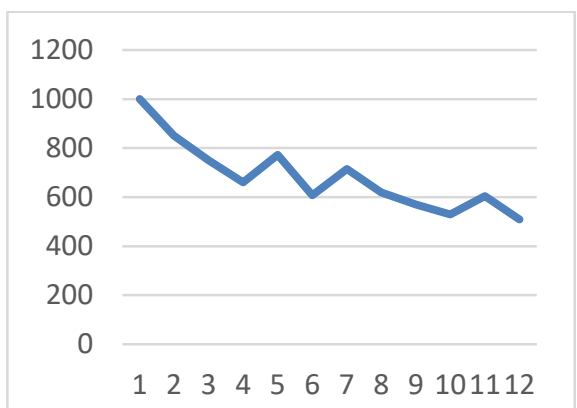

Gambar 6 plot data kertas Paper A

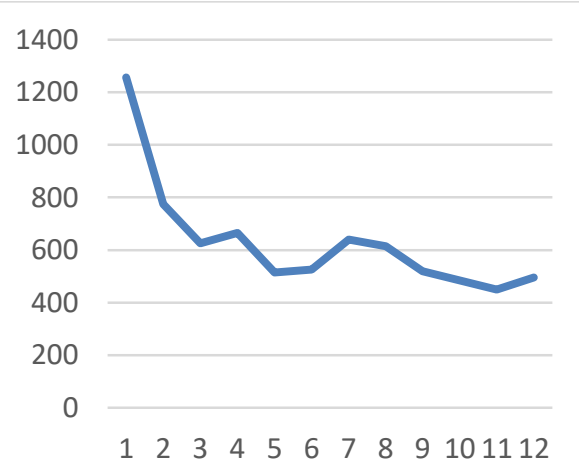

Gambar 7. plot data kertas HVS A3+

Kedua pola data penjualan terlihat bahwa penjualan kedua kertas mengalami penurunan dengan kata lain bahwa plot di atas berupa plot data trend menurun dikarenakan jika data ditarik garis lurus menunjukan penurunan sekuler jangka panjang di antara garis tersebut[6], Tipe data plot di atas dapat di ramalkan dengan menggunakan Double Exponential Smooting.

\subsection{Data Perhitungan}

Kegiatan dalam melakukan penelitian di suatu perusahaan memerlukan suatu tindakan serta analisa dengan tujuan untuk memberikan jawaban atau argument terhadap perusahaan. Analisa data pada penelitian ini menggunakan metode Double Exponential Smoothing dan pengujian validitas menggunakan metode MAPE (Mean Absolute Percentage Error).

\subsubsection{Perhitungan Kertas Paper A}

Menentukan nilai smoothing (S't) pertama dapat diketahui dengan menggunakan rumus persamaan (1) :

Alpha 0,3 berikut ini contoh perhitungannya :

$S^{\prime} 1=1000$

$S^{\prime} 2=(0,3) 850+(0,7) 1000=955$

$S^{\prime} 3=(0,3) 750+(0,7) 955=893,5$

$S^{\prime} 4=(0,3) 660+(0,7) 839,5=823,45$

$S^{\prime} 5=(0,3) 773+(0,7) 823,45=808,315$

Menentukan nilai smoothing (S't) pertama dapat diketahui dengan menggunakan rumus persamaan (2), dan perhitungannya adalah :

S"1 = 1000

$S^{\prime \prime} 2=(0,3) 955+(0,7) 1000=986,5$

$\mathrm{S}^{\prime \prime} 3=(0,3) 893,5+(0,7) 986,5=958,6$

S"4 $=(0,3) 823,45+(0,7) 958,6=918,055$

S"5 $=(0,3) 808,315+(0,7) 918,055=$

885,133

Menentukan nilai konstanta (at) dapat diketahui dengan menggunakan rumus persamaan (3) dan perhitungannya adalah :

$A 1=2(1000)-1000=1000$

$A 2=2(955)-986,5=923,5$

$A 3=2(893,5)-958,6=828,4$

$A 4=2(823,45)-918,055=728,845$

$A 5=2(808,315)-885,133=731,497$

Menentukan nilai konstanta (bt) dapat diketahui dengan menggunakan rumus persamaan (4) :

b1 $=\left(\frac{0,3}{(1-0,3)}\right)(1000-1000)=0$

b2 $=\left(\frac{0,3}{(1-0,3)}\right)(955-986,5)=-13,5$

b3 $=\left(\frac{0,3}{(1-0,3)}\right)(893,5-958,6)=-27,9$

b4 $=\left(\frac{0,3}{(1-0,3)}\right)(823,45-918,055)=-40,545$

b5 $=\left(\frac{0,3}{(1-0,3)}\right)(808,315-885,133)=-32,922$

Menentukan nilai peramalan $(\mathrm{Ft}+\mathrm{m})$ dapat diketahui dengan menggunakan rumus persamaan (5) :.

$\mathrm{F} 2=1000+0=1000$

$\mathrm{F} 3=923,5+(-13,5)=910$

$\mathrm{F} 4=828,4+(-27,9)=800$ 
$\mathrm{F} 5=728,845+(-40,545)=688$

$F 6=731,497+(-32,922)=698$

Berikut hasil perhitungan Paper A dengan alpha 0,3 ditunjukkan pada Tabel 2

Tabel 2. Hasil Perhitungan Paper A Alpha 0,3

\begin{tabular}{|c|c|c|r|r|r|r|c|}
\hline Bulan & jumlah & Xt & \multicolumn{1}{c|}{ S't } & \multicolumn{1}{c|}{ S"t } & nilai a & nilai b & F+1 \\
\hline JULI 2018 & 1000 & 1000 & 1000 & 1000 & 1000 & 0 & \\
\hline AGUSTUS 2018 & 850 & 850 & 955 & 986,5 & 923,5 & $-13,5$ & 1000 \\
\hline SEPTEMBER 2018 & 750 & 750 & 893,5 & 958,6 & 828,4 & $-27,9$ & 910 \\
\hline OKTOBER 2018 & 660 & 660 & 823,45 & 918,055 & 728,845 & $-40,545$ & 800 \\
\hline NOVEMBER 2018 & 773 & 773 & 808,315 & 885,133 & 731,497 & $-32,922$ & 688 \\
\hline DESEMBER 2018 & 607 & 607 & 747,9205 & 843,9693 & 651,8718 & $-41,1637$ & 698 \\
\hline JANUARI 2019 & 715 & 715 & 738,0444 & 812,1918 & 663,8969 & $-31,7775$ & 611 \\
\hline FEBRUARI 2019 & 620 & 620 & 702,631 & 779,3236 & 625,9385 & $-32,8682$ & 632 \\
\hline MARET 2019 & 570 & 570 & 662,8417 & 744,379 & 581,3045 & $-34,9445$ & 593 \\
\hline APRIL 2019 & 530 & 530 & 622,9892 & 707,9621 & 538,0164 & $-36,4169$ & 546 \\
\hline MEI 2019 & 605 & 605 & 617,5924 & 680,8512 & 554,3337 & $-27,1109$ & 501 \\
\hline JUNI 2019 & 510 & 510 & 585,3147 & 652,1902 & 518,4392 & $-28,6609$ & 527 \\
\hline JULI 2019 & \multicolumn{7}{|c|}{ PERAMALAN } \\
\hline
\end{tabular}

Jadi peramalan penjualan item kertas Paper A dibulan Juli 2019 dengan alpha 0,3 adalah 490.

\subsubsection{Perhitungan Kertas HVS A3+}

Perhitungan pada kertas hvs $\mathrm{A} 3+$ ini sama dengan perhitungan pada kertas Paper A dengan alpha 0,3 ditunjukkan pada Tabel 3.

Tabel 3. Hasil Perhitungan HVS A3+ Alpha 0,3

\begin{tabular}{|c|c|c|c|c|c|c|c|}
\hline Bulan & Jumlah & $\mathbf{X t}$ & $S^{\prime} \mathbf{t}$ & S"t & Nilai a & Nilai b & Ramalan \\
\hline JULI 2018 & 1256 & 1256 & 1256 & 1256 & 1256 & 0 & \\
\hline AGUSTUS 2018 & 775 & 775 & 1111,7 & 1212,71 & 1010,69 & $-43,29$ & 1256 \\
\hline SEPTEMBER 2018 & 625 & 625 & 965,69 & 1138,604 & 792,776 & $-74,106$ & 967 \\
\hline OKTOBER 2018 & 665 & 665 & 875,483 & 1059,668 & 691,2983 & $-78,9363$ & 718 \\
\hline NOVEMBER 2018 & 515 & 515 & 767,3381 & 971,9688 & 562,7074 & $-87,6989$ & 612 \\
\hline DESEMBER 2018 & 525 & 525 & 694,6367 & 888,7692 & 500,5042 & $-83,1996$ & 475 \\
\hline JANUARI 2019 & 640 & 640 & 678,2457 & 825,6121 & 530,8792 & $-63,1571$ & 417 \\
\hline FEBRUARI 2019 & 615 & 615 & 659,272 & 775,7101 & 542,8339 & $-49,902$ & 468 \\
\hline MARET 2019 & 520 & 520 & 617,4904 & 728,2442 & 506,7366 & $-47,4659$ & 493 \\
\hline APRIL 2019 & 485 & 485 & 577,7433 & 683,0939 & 472,3926 & $-45,1503$ & 459 \\
\hline MEI 2019 & 450 & 450 & 539,4203 & 639,9918 & 438,8488 & $-43,1021$ & 427 \\
\hline JUNI 2019 & 495 & 495 & 526,0942 & 605,8225 & 446,3659 & $-34,1693$ & 396 \\
\hline JULI 2019 & & & PERA & MALAN & & & 412 \\
\hline
\end{tabular}

Jadi peramalan penjualan item kertas HVS A3+ dibulan Juli 2019 dengan alpha 0,3 adalah 412.

\subsection{Implementasi Sistem}

Tampilan implementasi aplikasi peramalan penjualan kertas dengan metode Double Exponential Smooting:

\subsubsection{Halaman home}

Pada halaman ini menampilkan menu utama dari aplikasi, yaitu seperti input item, penjualan, forecasting DLL, tampilan tersebut tergantung pada hak akses pengguna aplikasi yang masuk.

\subsubsection{Halaman Item}

Pada halaman ini yaitu untuk menginputkan jenis item kertas yaitu kertas Paper A dan HVS A3+, berikut tampilan ditunjukkan pada Gambar 8.

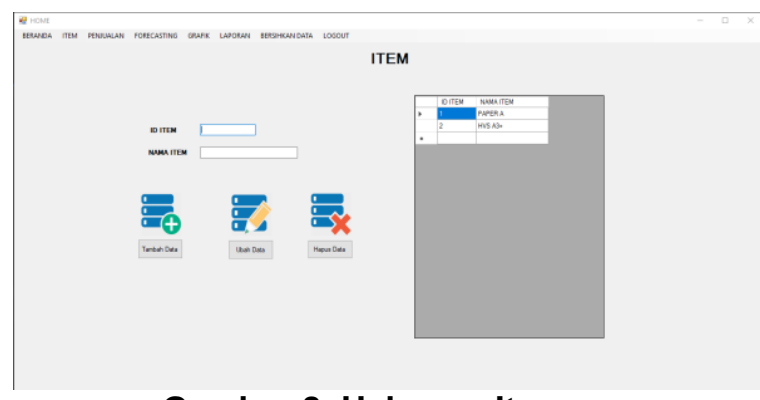

Gambar 8. Halaman Item

\subsubsection{Halaman Penjualan}

Pada halaman penjualan ini digunakan untuk menginputkan data penjualan kertas Paper A dan HVS A3+ perbulanya, berikut tampilan ditunjukkan pada Gambar 9. PENJUALAN

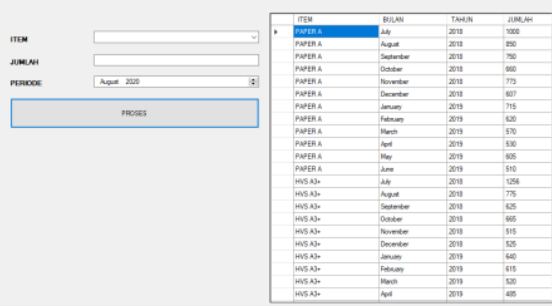

Gambar 9. Halaman Penjualan

\subsubsection{Halaman Forecasting}

Pada halaman forecasting ini berisi tampilan hasil peramalan dengan alpha terbaik dan hasil mape setiap alpha yang di gunakan, berikut tampilan ditunjukkan pada Gambar 10.

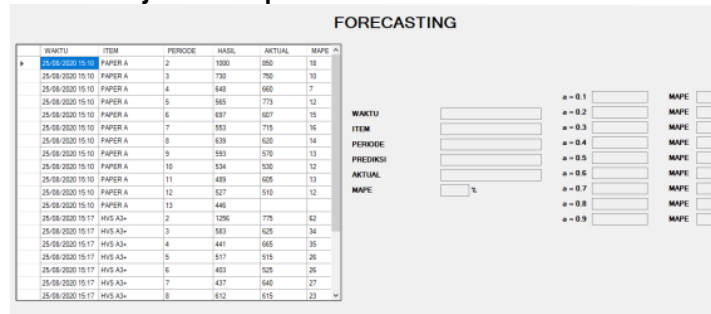

\section{Gambar 10. Halaman forecasting}

\subsubsection{Halaman Grafik}

Pada halaman grafik berisi tampilan pilihan grafik yang ingin ditampilkan, serta akan menampilkan grafik peramalan dan data penjualan, berikut tampilan ditunjukkan pada Gambar 11. 


\subsection{Uji validitas}

Metode pengukuran kesalahan peramalan yang digunakan adalah Mean Absolute Percentage Error (MAPE) dengan berdasarkan persamaan rumus (6) dan (7) [8]

\subsubsection{Hasil Uji Validitas Kertas Paper A}

Berikut merupakan hasil uji validitas Paper A ditunjukkan pada Tabel 4.

Tabel 4 Perhitungan MAPE Kertas Paper A

\begin{tabular}{|c|c|c|c|c|c|c|}
\hline XT & APE 0,3 & \multirow{12}{*}{ MAPE } & APE 0,4 & \multirow{12}{*}{ MAPE } & APE 0,5 & \multirow{12}{*}{ MAPE } \\
\hline 1000 & 0 & & 0 & & & \\
\hline 850 & 17,64706 & & 17,64706 & & 17,64706 & \\
\hline 750 & 21,33333 & & 17,33333 & & 13,33333 & \\
\hline 660 & 21,21212 & & 13,93939 & & 7,878788 & \\
\hline 773 & 10,99612 & & 18,11125 & & 22,76843 & \\
\hline 607 & 14,99176 & & 12,85008 & & 14,82702 & \\
\hline 715 & 14,54545 & & 18,18182 & & 19,58042 & \\
\hline 620 & 1,935484 & & 3,064516 & & 6,612903 & \\
\hline 570 & 4,035088 & & 4,385965 & & 5,438596 & \\
\hline 530 & 3,018868 & & 2,45283 & & 1,886792 & \\
\hline 605 & 17,19008 & & 18,01653 & & 18,5124 & \\
\hline 510 & 3,333333 & 10,85323 & 6,862745 & 11,07046 & 10,78431 & 11,60584 \\
\hline
\end{tabular}

Berdasarkan Tabel 4 maka diperoleh rata-rata kesalahan prediksi dengan menggunakan nilai $\alpha=0,3$ sebesar $10,85323 \%$ dengan tingkat akurasi $89,146774 \%, \alpha=0,4$ sebesar $11,07046 \%$ dengan tingkat akurasi $88,92954 \%$ dan $\alpha=$ 0,5 sebesar $11,60584 \%$ dengan tingkat akurasi $88,39416 \%$. hasil menujukkan bahwa peramalan termasuk baik karena tingkat error di bawah $20 \%$ menurut [3].

\subsubsection{Hasil Uji Validitas Kertas HVS A3+} Berikut merupakan hasil uji validitas HVS A3+ ditunjukkan pada Tabel 5.

Tabel 5 Perhitungan MAPE Kertas HVS A3+

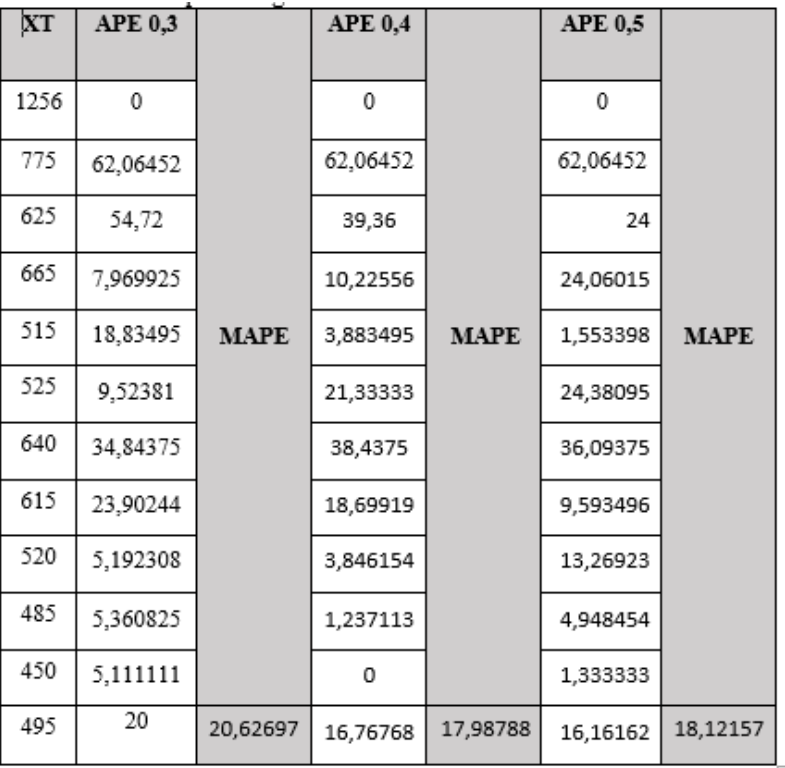

Berdasarkan Tabel 5 maka diperoleh rata-rata kesalahan prediksi dengan menggunakan nilai $\alpha=0,3$ sebesar $20,62697 \%$ dengan tingkat akurasi $79,37303 \%, \alpha=0,4$ sebesar $17,98788 \%$ dengan tingkat akurasi $82,01212 \%$ dan $\alpha=$ 0,5 sebesar $18,12157 \%$ dengan tingkat akurasi $81,87843 \%$. hasil menujukkan bahwa peramalan termasuk baik karena tingkat error di bawah $20 \%$ menurut [3].

\subsubsection{Uji Validitas perbandingan peramalan dan aktual}

Berikut hasil pengujian peramalan aplikasi dengan perbandingan nilai aktual pada bulan yang sama guna mengetahui hasil selisih peramalan dan aktual, hasil pengujian ditampilkan pada Tabel 5 berikut.

Tabel 5 Perhitungan MAPE Kertas HVS A3+

\begin{tabular}{|c|c|c|c|c|c|c|}
\hline Kertas & Bulan & Aktual & Peramalan & Selisih & $\begin{array}{l}\text { APE } \\
(\%)\end{array}$ & $\begin{array}{c}\text { MAPE } \\
(\%)\end{array}$ \\
\hline \multirow{5}{*}{$\begin{array}{c}\text { Paper } \\
\text { A }\end{array}$} & Juli 2019 & 395 & 446 & 51 & 12,91139 & \multirow{5}{*}{14,97626} \\
\hline & $\begin{array}{c}\text { Agustus } \\
2019\end{array}$ & 415 & 413 & 2 & 0,481928 & \\
\hline & $\begin{array}{c}\text { September } \\
2019\end{array}$ & 485 & 386 & 99 & 20,41237 & \\
\hline & $\begin{array}{c}\text { Oktober } \\
2019\end{array}$ & 504 & 419 & 85 & 16,86508 & \\
\hline & $\begin{array}{c}\text { November } \\
2019\end{array}$ & 570 & 432 & 138 & 24,21053 & \\
\hline \multirow{5}{*}{$\begin{array}{l}\text { Hvs } \\
\mathrm{A} 3+\end{array}$} & Juli 2019 & 450 & 474 & 24 & 5,333333 & \multirow{5}{*}{8,990314} \\
\hline & $\begin{array}{c}\text { Agustus } \\
2019 \\
\end{array}$ & 426 & 428 & 2 & 0,469484 & \\
\hline & $\begin{array}{c}\text { September } \\
2019\end{array}$ & 515 & 409 & 106 & 20,58252 & \\
\hline & $\begin{array}{c}\text { Oktober } \\
2019 \\
\end{array}$ & 547 & 495 & 52 & 9,506399 & \\
\hline & $\begin{array}{c}\text { November } \\
2019 \\
\end{array}$ & 585 & 532 & 53 & 9,059829 & \\
\hline
\end{tabular}


Perbandingan peramalan 5 periode didapat bahwa pada Paper A rata-rata error sedikit naik di bandingkan pada peramalan awal, yaitu $12 \%$ naik menjadi $14 \%$ namun peramalan tersebut masih dikatakan baik karena error masih dibawah $20 \%$ menurut [3], serta pada peramalan HVS A3+ rata-rata error mengalami penurunan, yaitu pada peramalan awal $18 \%$ menjadi $8 \%$ dimana hal tersebut sangatlah bagus peramalan berjalan dengan baik.

\section{PENUTUP}

\subsection{Kesimpulan}

Berdasarkan pembahasan diatas maka dapat disimpulkan sebagai berikut:

1. Terciptanya sistem peramalan penjualan yang dapat meramalkan penjualan kertas dengan metode Double Exponential Smooting. Sistem yang telah dibangun ini dapat digunakan untuk membantu pengambilan keputusan pembelian bahan baku.

2. Pada pengujian validitas dengan nilai $\boldsymbol{\alpha}=$ 0,3; 0,4 ; 0,5 didapatkan hasil:

a. Pada hasil Paper A diperoleh rata-rata kesalahan prediksi dengan menggunakan nilai $\alpha=0,3$ sebesar $10,85323 \%$ dengan tingkat akurasi $89,146774 \%, \quad \alpha=0,4$ sebesar $11,07046 \%$ dengan tingkat akurasi $88,92954 \%$ dan $\alpha=0,5$ sebesar $11,60584 \%$ dengan tingkat akurasi $88,39416 \%$,dan di dapat hasil alpha terbaik pada alpha 0,3 dengan hasil peramalan 490.

b. Pada HVS A3+ diperoleh rata-rata kesalahan prediksi dengan menggunakan nilai $\alpha=0,3$ sebesar $20,62697 \%$ dengan tingkat akurasi $79,37303 \%, \quad \alpha=0,4$ sebesar $17,98788 \%$ dengan tingkat akurasi $82,01212 \%$ dan $\alpha=0,5$ sebesar $18,12157 \%$ dengan tingkat akurasi $81,87843 \%$, dan di dapat hasil alpha terbaik pada alpha 0,4 dengan hasil peramalan 441.

3. Pengujian aplikasi sistem didapatkan hasil:

a. Pada peramalan Paper A di aplikasi didapat alpha terbaik pada periode ke 12 yaitu sebesar 0,3 dengan error sebesar $12 \%$ dan tingkat akurasi sebesar $88 \%$, dimana alpha tersebut digunakan untuk meramalkan periode ke 13 dan menghasilkan nilai peramalan yaitu 446 .

b. Pada peramalan HVS $\mathrm{A}_{+}$di aplikasi didapat alpha terbaik pada periode ke 12 yaitu sebesar 0,6 dengan error sebesar $18 \%$ dan tingkat akurasi sebesar $82 \%$, dimana alpha tersebut digunakan untuk meramalkan periode ke 13 dan menghasilkan nilai peramalan yaitu 474 .

4. Perbandingan peramalan 5 periode didapat bahwa pada Paper A rata-rata error sedikit naik dibandingkan pada peramalan awal yaitu $12 \%$ naik menjadi $14 \%$ namun peramalan tersebut masih dikatakan baik karena error masih dibawah $20 \%$, serta pada peramalan HVS A3+ rata-rata error mengalami penurunan yaitu pada peramalan awal $18 \%$ menjadi $8 \%$ dimana hal tersebut sangatlah bagus peramalan berjalan dengan baik.

\subsection{Saran}

Saran untuk mengembangkan atau menyempurnakan sistem peramalan ini yaitu sebagai berikut:

1. Dalam penggunaan sistem peramalan ini pengguna diharapkan teliti dalam penginputan penjualan setiap periodenya, karena setiap kesalahan sedikit saja dapat menghasilkan hasil peramalan yang berbeda pula.

2. Aplikasi ini dapat dikembangkan guna dapat meramalkan jenis kertas lain baik itu menggunakan metode yang sama ataupun berbeda agar lebih bermanfaat nantinya.

3. Aplikasi dapat dikembangkan menggunakan basis lain contoh seperti berbasis Web yang nantinya dapat lebih mudah diakses.

\section{DAFTAR PUSTAKA}

[1] A. Listian and S. D. W. 12STIE, "Analisis Pengelolaan Persedian Barang Dagang Untuk Mengoptimalkan Laba," STIE Kesuma Negara Blitar, vol. 4, no. 1, pp. 95-103, 2019.

[2] Karmawati and W. Fuadi, "Peramalan Penjualan Elektronik Menggunakan Metode Single Exponential Smoothing Dan Double Exponential Smoothing Pada 
Toko Lina Mandiri," J. Sist. Inf. ISSN 2598-599X, vol. 1, pp. 27-53, 2014.

[3] M. N. Fawaiq, A. Jazuli, and M. M. Hakim, "Prediksi hasil pertanian padi di kabupaten kudus dengan metode brown's double exponential smoothing," vol. 4, pp. 78-87, 2019.

[4] H. Jogiyanto, "Sistem Teknologi Informasi," Ranc. Bangun Sist. Inf. Penjualan Pada Mina Mark. Benowo, pp. 6-28, 2005.

[5] A. Lieberty and R. V. Imbar, "Sistem Informasi Meramalkan Penjualan Barang Dengan Metode Double Exponential Smoothing (Studi Kasus: PD. Padalarang Jaya)," J. Tek. Inform. dan Sist. Inf., vol. 1, no. 1, 2015.

[6] S. Hanief and A. Purwanto, "Peramalan Dengan Metode Exponential Smoothing Dan Analisis Sistem Untuk Penentuan Stok Atk ( Kertas a4 )," J. Teknol. Inf. dan Komput., vol. 3, no. 1, pp. 279-284, 2017.

[7] T. D. Andini and P. Auristandi, "Peramalan Jumlah Stok Alat Tulis Kantor di UD Achmad Jaya Menggunakan Metode Double Exponential Smoothing," J. IIm. Teknol. Inf. Asia, vol. 10, no. 1, pp. 1-10, 2016.

[8] S. Makridakis, S. Wheelwright C, and V. E. McGee, Metode dan Aplikasi Peramalan. Jakarta: Binarupa Aksara, 1999.

[9] T. Hendriani, M. Yamin, and A. P. Dewi, "Sistem Peramalan Persediaan Obat Dengan Metode Weight Moving Average Dan Reorder Point (Studi Kasus: Puskesmas Soropia)," semanTIK, vol. 2, no. 2, pp. 207-214, 2017. 